Volume 4 Nomor 1, Januari-Juni 2020: hlm. 55-66.

Fakultas Hukum, Universitas Lampung,

Bandar Lampung, Lampung, Indonesia.

E-ISSN: 2598-3105 P-ISSN: 2723-2581

http://jurnal.fh.unila.ac.id/index.php/cepalo

\title{
SAFEGUARDING HORMANI BROTHERS AND SISTERS AND CARRYING OUT LEGAL PROTECTION AGAINST ECOSYSTEM CONSERVATION IN MALUKU
}

\author{
La Ode Angga
}

Faculty of Law, Universitas Pattimura, Ambon, Email: laodeangga@yahoo.com

Submitted: March 4, 2020; Reviewed: March 31, 2020; Accepted: April 20, 2020

DOI: $10.25041 /$ cepalo.v4no1.1882

\begin{abstract}
Brothers and Sisters of people in Maluku have the same hopes and ideals to always maintain peace in the land of the Kings of this Country. Harmony that is manifested in togetherness, friendship, brotherhood, love between fellow children in Maluku, and the silatu of the womb. It will motivate high civilization between public and indigenous people value if Brothers and Sisters of Maluku maintain peace that will ensure harmony among people. On the other hand, it will preserve ecosystems in Maluku which will create Harman between humans and the environment. This research explains the forms of basudara people's activities as a form of implementation of peace preservation. This study uses a normative legal approach; normative legal research is carried out using appropriate methods based on the scientific characteristics of legal science. Moreover, this study discusses harmony maintenance of brothers in Maluku that perform Legal Protection against Ecosystem Conservation in Maluku. The research finds that the one form of keeping peace in Maluku is in the form of togetherness, friendship, brotherhood and love. It is believed that these principles will provide positive energy in humanity welfare. Therefore, the Government of Maluku must encourage awareness of both general public and indigenous people of Maluku.
\end{abstract}

Keywords: Brothers, Ecosystem, Protection, Sistersand.

\section{A. Introduction}

All Brothers And Sisters and people in Maluku (children of the State of Maluku) have the same hopes and ideals to always maintain peace in the land of the Kings of this Country. ${ }^{1}$ The above expression is a hope for all Brothers and Sistersand people in Maluku ${ }^{2}$ regardless of ethnicity, religion, race, skin color, gender, old and young. All of that is done with the same goal of maintaining and preserving the lives of Maluku people who are peaceful, safe and in

\footnotetext{
${ }^{1}$ Marcus Mietzner, "POLITICAL CONFLICT RESOLUTION AND DEMOCRATIC CONSOLIDATION IN INDONESIA: THE ROLE OF THE CONSTITUTIONAL COURT," Journal of East Asian Studies 10, no. 3 (2010): 397-424, 398, DOI: 10.1017/S1598240800003672.

${ }^{2}$ George A. Gates, Nat N. Couropmitree, and Richard H. Myers, "GENETIC ASSOCIATIONS IN AGERELATED HEARING THRESHOLDS," Archives of Otolaryngology-Head \& Neck Surgery 125, no. 6 (1999): 654-659, 655, DOI: 10.1001/archotol.125.6.654.
} 
harmony. ${ }^{3}$ To realize this, all elements of the Brothers And Sistersand community in Maluku must join hands in carrying out basudara activities to build harmony. ${ }^{4}$ Harmony is a must in building the nation, because it is to realize the ideals of the nation in accordance with Pancasila. The Pancasila precept which is the ideal of the entire nation is the second principle which reads the unity of Indonesia.

According to Watloly, ${ }^{5}$ the ancestors of the past have been able to build a culture of peaceful life, harmony in a bond of noble brotherhood, the ancestors have proven an achievement of community life that has always been idealized as an intelligent performance, custom and religion, harmony in life, especially harmony in religious life as the value of other social nobleness, more affirms a "prophetic conscience" 6 that presents the work of joy, peace and true harmony in building a lasting and sustainable life order in Maluku. We are all historical witnesses who have become legitimate heirs to the legacy of traditional values ${ }^{7}$ once again, the nobleness of reasoning based on the spirit of transcendence makes this island region previously known to be very tolerant, even once one of the icons of peace in Indonesia. the reality of multiculturalism and pluralism, as reflected in the basic views of Siwalima. Based on Siwalima's basic views, Maluku basudara people can live together peacefully and mutually pro-existence between Salam (Islamic Community) and Sarane (Christian Community), Pela, gandong, Larvul Ngabal, 'Aini Ain and so on.

Harmony that is manifested in togetherness, friendship, brotherhood, love between fellow children in Maluku, and the silatu of the womb, will be more beautiful and have a high civilization value if the people of Brothers and Sistersand in the Land of the Kings on one hand maintain peace that will give birth harmony among people and on the other hand, preserve the preservation of ecosystems in Maluku which will give birth to the harman between humans and the universe and the environment. Talking about protecting the ecosystem in Maluku, one of the protected ecosystems in Maluku is an endemic and endangered species of bird species. Endemic bird species of protected and endangered species exist in several districts in Maluku Province. Such as East Seram District (SBT), West Seram District (SBB), Central Maluku District (Malteng) and Southwest Maluku District (MBD). ${ }^{8}$

The obligation of the Brothers and Sistersand people in Maluku to create wealth on the one hand and to protect and preserve the ecosystem on the other hand is like two sides of the same important coin that aims to maintain balance. On the one hand there will be a balance in society in the form of harmony with the community ${ }^{9}$ of human society with humans and on the other hand there will be a balance or harmony between humans and their environment,

\footnotetext{
${ }^{3}$ Riswanda Setiadi et al., "A PEACE PEDAGOGY MODEL FOR THE DEVELOPMENT OF PEACE CULTURE IN AN EDUCATION SETTING,” The Open Psychology Journal 10, no. 1 (2017): 182-189, 184, DOI: $10.2174 / 1874350101710010182$.

${ }^{4}$ La Ode Angga, "PRINSIP KEHATI-HATIAN DI BIDANG PENGELOLAAN LINGKUNGAN HIDUP DALAM PERATURAN DAERAH RENCANA TATA RUANG WILAYAH PROVINSI MALUKU," Rechtidee 12, no. 1 (2017): 134-165, 134, DOI: 10.21107/ri.v12i1.3130.

5 http://www.kompasiana.com/azufri/membangun-budaya-perdamaian-di-maluku_54f73687a33311af688b47ca, accessed on May 23, 2017.

${ }^{6}$ Harry Walker, "SOULFUL VOICES: BIRDS, LANGUAGE AND PROPHECY IN AMAZONIA," Tipití Journal of The Society for the Anthropology of Lowland South America 8, no. 1 (2010): 1-21, 5.

${ }^{7}$ Iratxe Calvo-Mendieta, Olivier Petit, and Franck-Dominique Vivien, "THE PATRIMONIAL VALUE OF WATER: HOW TO APPROACH WATER MANAGEMENT WHILE AVOIDING AN EXCLUSIVELY MARKET PERSPECTIVE," Policy and Society 30, no. 4 (2011): 301-310, 302, DOI: 10.1016/j.polsoc.2011.10.006.

${ }^{8}$ La Ode Angga, Meraat Perdamaian Dan Melestraikan Ekosistem Maluku (Ambon: Pattimra University Prees, 2017), 21.

${ }^{9}$ Lindsey A. Bruckerhoff et al., "HARMONY ON THE PRAIRIE? GRASSLAND PLANT AND ANIMAL COMMUNITY RESPONSES TO VARIATION IN CLIMATE ACROSS LAND-USE GRADIENTS," Ecology 101, no. 5 (2020) DOI: 10.1002/ecy.2986.
} 
both of which are very important (urgent) to be guarded, cared for and preserved by Brothers And Sistersand people in the land of King - This king.

In maintaining peace and carrying out protection and conservation of ecosystems in Maluku, there are forms of activities that must be carried out by basudara people in Maluku, so that they remain lasting and / or sustainable. In this article the author wants to explain the forms of Maluku people basudara activities as a form of implementation of peace preservation that will give birth to harmony with others and preserve ecosystems in Maluku, which will give birth to harmony between humans and the environment. Referring to the formulation of the problem, this study uses a normative legal approach, normative legal research is carried out using appropriate methods based on the scientific characteristics of legal science. This study discusses calmly Maintaining the harmony of brothers in Maluku Perform Legal Protection Against Ecosystem Conservation in Maluku.

\section{B. Discussion}

\section{Forms of Activities in Preserving Peace in Maluku}

In caring for peace that engenders harmony and protects and preserves ecosystems in Maluku, all components of the Brothers and Sistersand community in Maluku must be involved and actively participate and work hard, and teeth, without tiring to achieve those hopes and ideals. There are a number of activities that can encourage the formation of sustainable peace in Maluku Province. ${ }^{10}$ The activities carried out have a deep meaning in realizing the ideals of the group.

\section{a. Conduct Dialogue}

The Governor of Maluku, Said Assagaff, as a leader in the Land of the Kings has said in a discussion and book launch related to mediation, reconciliation road maps and conflict monitoring mechanisms in Ambon, at the hotel: "If we can maintain a peaceful life, our region will advance and be respected by other regions. I am sure, without the support and active participation of all elements of society, what the Regional Government is fighting for will not mean anything".

The Governor of Maluku continued on the occasion, ${ }^{12}$ also giving appreciation, related to the implementation of dialogue held by the Maluku Tifa Damai Institute. The Tifa Damai Institute of Maluku is an institution engaged in peace in Maluku, so far it has demonstrated its role and function, as well as contributing significantly, as one of the driving forces in creating a safe, harmonious and peaceful social order. The Maluku Governor further said: ${ }^{13}$

"Through this dialogue, he hopes, various efforts will expand the reach of the program and increase the understanding of more and more stakeholders related to dialogue and mediation between religious adherents in Ambon. So that, in the future it is expected that synchronization of development activities that are concerned can strengthen conflict monitoring and mediation strategies, can be carried out on target. As the main actor in building life together among fellow children of the nation, he explained, the community in the context of individuals and groups, should have the awareness to build a life together in a safe, harmonious and peaceful atmosphere. "Only in a safe, harmonious and peaceful atmosphere

\footnotetext{
${ }^{10}$ Angga La Ode, "PERLINDUNGAN HUKUM TERHADAP JENIS BURUNG LANGKA ENDEMIK YANG TERANCAM PUNAH DI MALUKU”, Jurnal Kosmik Hukum, (2018): 158-167, 159, DOI: 10.30595/kosmikhukum.v18i2.3459.

${ }^{11} \mathrm{http}: / /$ rayapos.com/anak-anak-negeri-harus-jaga-perdamaian-maluku/, accessed on May 23, 2017.

${ }^{12} \mathrm{http} / / /$ rayapos.com/anak-anak-negeri-harus-jaga-perdamaian-maluku/, accessed on May 23, 2017.

${ }^{13}$ http://rayapos.com/anak-anak-negeri-harus-jaga-perdamaian-maluku/, accessed on May 23, 2017.
} 
can we carry out development, for the advancement and welfare of the people in Maluku Province".

John Ruhulessin: "Said, first of all, I put high respect and appreciation for joint efforts to care for true peace in Maluku in particular and Indonesia in general, one of which was through the National Workshop held by Wantannas last year (2018) in Jakarta" ${ }^{14}$ Peace and harmony are very important for the development of the nation nationally and regionally. Especially in Maluku province, because small problems can have a bad impact on the sustainability of national unity.

Maintaining the peace of basudara people in Maluku according to Agus Ulahaiyanan, ${ }^{15}$ can be done by: Developing dialogue or mutual communication, which is based on awareness of;

1) The existence of similarities or differences that cannot be denied and removed, according to the nature or dignity and human dignity;

2) There are similarities in values and problems and universal needs related to humanity, such as truth, justice, human rights, brotherhood and love; and

3) The fact of shared life in diversity and relationships and dependence on each other.

In the book Caring for Peace; 20 Years of Conflict underway "Maluku Family culture which has been maintained for hundreds of years through local wisdom of Pela and Gandong seems to be left unlucky. Luckily, through various serious efforts by many parties, peace in the Maluku Islands has been restored". ${ }^{16}$

\section{b. Building Harmony and Tolerance Among Religious People}

According to Watloly harmony and tolerance between religious communities ${ }^{17}$ is a consequence and intrinsic need of universal humanity, which cannot be denied and must be cultivated by every religious person because humans are essentially living things that: ${ }^{18}$

1) Individual and communal simultaneously living together, grouping themselves on a certain basis, need each other, relate to each other, influence each other;

2) Having the same dignity, human values, and human rights, existence or existence, problems and needs, ideology and ideals;

3) Having a peculiarity that distinguishes individuals from one another and groups from one group to another;

4) Having inner freedom (will) and outward (action), but simultaneously can also influence and be influenced;

5) Having "egositis" and "altroistic" tendencies, both individually and communally;

6) Having the mind, conscience and virtue to think and know, judge and decide, and act or do;

7) Have values and norms: custom / culture, statehood, religion.

Respect for other religions / religions, living in harmony and peace with other religious communities, is not only a religious requirement or obligation, but broader and deeper than

\footnotetext{
14 https://terasmaluku.com/merawat-damai-sejati-di-maluku-dan-indonesia-oleh-dr-john-ruhulessin-akademisiukim-ambon/, accessed on February 9, 2020.

$15 \mathrm{https}$ //stpakambon.wordpress.com/membangun-kerukunan-dan-toleransi-antar-umat-beragama-di-maluku/, accessed on May 22, 2017.

${ }^{16} \mathrm{https}$ //www.gramedia.com/products/merawat-perdamaian-20-tahun-konflik-maluku, accessde on February 9, 2020.

17 L. Aarssen, L. W. Crimi, "BEYOND SIMPLE PLANNING: EXISTENTIAL DIMENSIONS OF CONVERSATIONS WITH PATIENTS AT RISK OF DYING FROM HEART FAILURE.," Journal of Pain and Symptom Management 54, no. 5 (2017): 637-644, 640, DOI: 10.1016/j.jpainsymman.2017.07.041.

$18 \mathrm{https}: / /$ stpakambon.wordpress.com/membangun-kerukunan-dan-toleransi-antar-umat-beragama-di-maluku/, accessed on May 6, 2017.
} 
that, because of humanity. ${ }^{19}$ Harmony and tolerance between people, both religious, is a demand of human needs and obligations of every person. Harmony and tolerance between religious communities is a consequence of our human nature. ${ }^{20}$ Therefore, if there are people who damage or reject harmony and tolerance between religious communities, it is the same as those who destroy or reject humanity itself. ${ }^{21}$

\section{Building a Peace Community (Agent) that Creates a Feeling of Being Senasip as Maluku Moluccac People}

In 2008 between ojeg drivers in Christian settlements (Passo) and Islam (Tulehu) established an agreement to re-establish harmony and maintain peace. ${ }^{22}$ By Christmas, Muslim ojeg drivers can stay in Christian settlements. Conversely when Eid al-Fitr, Christian ojeg drivers operate in Muslim areas. Passo Youth cooperates with Tulehu youth to roll ojeg at Christmas and New Year. Likewise, during Eid al-Fitr, we look for passengers in Tulehu, "said Yafet Koedoeboen, a motorcycle taxi driver from Passo who was on Jalan Baru, Manusela.

To ensure comfort and anticipate bad things, Jafet, who is also Passo's youth leader, made a notice to fellow ojeg drivers, that a few days before Christmas and New Year, the base had to be emptied for ojeg drivers from Tulehu. "Every Eid Al-Fitr, we deliberately do not park motorbikes in the base. Christian ojek drivers already know that. For two days they were looking for passengers here, "said Abdullah Rumalean (25), an ojeg driver at the Batu Merah Dalam base. The same confession was also said by Iskandar Rumodar (25) and some of his friends who hung out in Christian settlements at Christmas. At that time, they took the passengers to Hatalae, South Leitimur District, the majority of which were Christians. "Basudara (brothers) Christians are very open to accept and respect us. They say, just ojeg. No need to worry, "said Iskandar.

The harmony and peace between the two groups shows that there are efforts to improve in society. This improvement effort is very important for the sustainability of society in the future, because with simple things like those done by the two groups of society, namely people from the Christian religion (Passo) to the Islamic community (Tulehu) will have an impact on everyone who can have a sense of tolerance society in a religious context. This action strongly reflects the mutual respect in accordance with the implementation of the first principle of Pancasila and is in accordance with what is stated in the Indonesian constitution. Even though the state has not taken action, these people have realized the obligation to respect each other among religious people. Awareness of the law that has occurred provides a positive spirit for the government. This positive spirit must be transmitted to law enforcement officials, so that they are more enthusiastic in maintaining a sense of tolerance in Indonesia, especially in the Maluku region.

\section{Forms of Activities In Protecting Ecosystems in Maluku}

\footnotetext{
${ }^{19}$ Nazmudin, "KERUKUNAN DAN TOLERANSI ANTAR UMAT BERAGAMA DALAM MEMBANGUN KEUTUHAN NEGARA KESATUAN REPUBLIK INDONESIA (NKRI)," Journal of Government and Civil Society 1, no. 1 (2018): 23-39, 23, DOI: 10.31000/jgcs.v1i1.268.

${ }^{20}$ Casram, "MEMBANGUN SIKAP TOLERANSI BERAGAMA DALAM MASYARAKAT PLURAL," Wawasan: Jurnal Ilmiah Agama Dan Sosial Budaya 1, no. 2 (2016): 187-198, 180, DOI: 10.15575/jw.v1i2.588.

$21 \mathrm{https} / / /$ stpakambon.wordpress.com/membangun-kerukunan-dan-toleransi-antar-umat-beragama-di-maluku/, accessed on May 22, 2017.

${ }^{22}$ Gilbert R. Winham and H. Eugene Bovis, "AGREEMENT AND BREAKDOWN IN NEGOTIATION: REPORT ON A STATE DEPARTMENT TRAINING SIMULATION,” Journal of Peace Research 15, no. 4 (1978): 285-303, 285, DOI: 10.1177/002234337801500401.
} 
In establishing a relationship between humans and the environment compared ${ }^{23}$ to the two sides of the coin above, Otto Soemarwoto said: "Humans, like all living things, interact with their environment. Humans affect the environment and vice versa humans are influenced by the environment". ${ }^{24}$ Based on this opinion, humans have an important role in an environment. The important role of human action is closely related to the impact of these activities. There are two kinds of impacts: first, positive impacts and; the second is a negative impact. Furthermore, dealing with 'humans who are influenced by their environment' means that the environment has an important role in human survival. The relationship between the two seems to influence each other. Bad / damaged environmental conditions will also have a bad impact on human life. However, if environmental conditions are very good, it will have a good impact on a whole human life.

Following Otto Soemarwoto stated: ${ }^{25}$

"Ecosystem is the arrangement of environmental elements which constitutes a whole and integrated whole in shaping the balance, stability, and productivity of the environment, a central concept in ecology is the ecosystem, namely an ecological system formed by the interrelationships between living things and their environment".

Opinion of Otto Soemarto explains the protection of ecosystems in life. Protect ecosystem in one unity of the environment is very important to provide a stable condition. Ecosystem has a very important role in the concept of ecology. Relationship between organsm and others is a form of an ecological system. The purpose of forming an ecosystem is that the environment can always intact from the all factors that are in it.

One of the environmental components that holds the key in the ecosystem is humans. The role of humans in ecosystems according to Moestadji, ${ }^{26}$ that as with human life in a society, ecosystems are also controlled by the natural law of energy which is called the law of thermodynamics. There are two natural laws on energy that need attention, namely the first themodynamic law (the law on energy conservation) and the second thermodynamic law ${ }^{27}$ (that energy is not entirely available for carrying out work).

Indonesia has many ecosystems including endemic rare bird species ecosystems, one area that has endemic rare bird species is in Maluku. Such as Cedrawasi birds found in West Southeast Maluku Regency, Cassowary in East Seram District (SBT) and West Seram District (SBB), parrots in Seram and Nuri birds ${ }^{28}$ in Maluku. Endemic rare bird species that exist in Maluku Province from year to year have decreased population, this is caused by several factors including:

a. The existence of massive deforestation (in a large area);

The explanation of these factors can be seen from the impact. Excessive deforestation will destroy the habitat of these birds of paradise. These birds will move when their natural habitat has been damaged as a result of this deforestation, when the transition period to new habitats will reduce the number of birds of paradise massively.

\footnotetext{
${ }^{23}$ Patricia M. C. Huijbers et al., "ROLE OF THE ENVIRONMENT IN THE TRANSMISSION OF ANTIMICROBIAL RESISTANCE TO HUMANS: A REVIEW," Environmental Science \& Technology 49, no. 20 (2015): 11993-12004, 11993, DOI: 10.1021/acs.est.5b02566.

${ }^{24}$ Otto Soemarwoto, Analisis Mengenai Dampak Lingkungan (Gadja Mada University Press, Yogyakarta, 2005), 17.

${ }^{25} \mathrm{Ibid}$.

${ }^{26}$ https://maktabahgoibiyah.wordpress.com/2008/12/31/pengantar-hukum-lingkungan/, accessed on May 22, 2017.

${ }^{27}$ Takahiro Sagawa and Masahito Ueda, "SECOND LAW OF THERMODYNAMICS WITH DISCRETE QUANTUM FEEDBACK CONTROL," Physical Review Letters 100, no. 8 (2008): 40-80, 40, DOI: 10.1103/PhysRevLett.100.080403.

${ }^{28}$ Irfan Rosyadi et al., "PERILAKU MEMELIHARA BURUNG PARUH BENGKOK DI MALUKU UTARA," Acta VETERINARIA Indonesiana 3, no. 2 (2016): 51-57, 52, DOI: 10.29244/avi.3.2.51-57.
} 
b. Costs provided by the government to carry out rehabilitation and conservation are minimal;

One of the other inhibiting factors is the problem of financing rehabilitation and conservation. Serious conservation must be balanced with sufficient financial conditions. Conservation-related needs require material support from related parties. Less efforts made by the government will have an adverse impact on the survival and existence of the bird of paradise. The state must be ready to take responsibility for the consequences of the extinction of the bird of paradise. If this happens, the country will experience non-material losses due to the loss of the bird of paradise which is very valuable to Indonesia.

c. Based on the 2010 Revised State Budget (APBN) plan whereby a special budget allocated for rehabilitation and conservation of endemic endangered species including endemic endangered bird species in Maluku Province is Rp. 100 billion or about one forty of the budget allocated for the forestry sector, which should be 1 trillion; Funds issued by the state are minimal for handling this problem. Considering this problem is a very serious for the survival of birds of paradise. The government and Indonesia's representative institutions as the parties holding the authority in determine the state budget must increase the allocation of funds. Both parties must have the same spirit and ideals to solve this problem seriously.

d. The occurrence or number of illegal trade / illegal carried out certain elements.

The problem of illegal bird of paradise trade is a classic problem that continues to occur every year. The beauty of bird of paradise feathers is the selling point of the bird of paradise. High demand makes the market value of birds of paradise increase rapidly. In relation to this demand, the supply value will increase.

\section{Endemic Rare Birds In Maluku Province}

\section{a. Cendrawasih Birds}

You are certainly familiar with the bird of paradise. This beautiful feathered bird is called a "bird from heaven" because of its beauty like an angel descending from heaven. Indonesia is really fortunate to have a unique bird of Papua that has been legendary throughout the earth. Imagine, from around 40 species of paradise in the world, 27 of them are in Indonesia.

The bird of paradise is unique from other birds. The main characteristic of this bird is the color of its feathers, the brightness of the feathers of this bird is very beautiful to the viewer. Various types of bird plumage color are green, red, yellow and the last is blue. Cendrawasih birds are usually given names based on the colors on their bodies. Examples of naming these birds include the names Little Yellow Bird, Big Yellow Bird, and Red Bird of Paradise Birds of Paradise are a family of animals with the order Passeriformes. Many sizes of this bird of paradise, the King Bird of Paradise jebis has a size of $15 \mathrm{~cm}$, and other types such as the Black Sicklebill which has a body shape of $110 \mathrm{~cm}$. Cendrawasih birds have extraordinary beauty. The reduction in the number of birds of paradise is due to the causes of deforestation in Indonesia. The habitat of birds of paradise is very threatened. Given the bird of paradise is a bird that is very rare in Indonesia and is a bird that is protected by law. ${ }^{29}$

\section{b. Types of Parrots}

The Maluku Cockatoo or in its scientific name Cacatua moluccensis is a medium-sized bird, with a length of about $52 \mathrm{~cm}$, of the genus Cacatua. This bird has white feathers mixed in pink. There was a large pink crest on his head that could be enforced. Flying feathers and

29 https://travel.detik.com/travel-news/d-4600467/7-fakta-menarik-tentang-cendrawasih-si-burung-surga, accessed on October,1 2020. 
yellowish orange tail. Female birds are similar, and are usually larger than male birds. Endemic to Indonesia. the area of distribution for Maluku is in South Maluku. This species is only found in primary and secondary forests of Seram Island, Ambon, Haruku Island and Saparua. A number of Maluku's parrot populations are protected at Manusela National Park, which is one of the last places to find these birds in wild habitats.

These birds eat small fruits, various types of nuts, and various types of seeds as well insects and their larvae. The original habitat of this bird is in lowland rain forests. The altitude where these birds live can reach 1,000 meters. ${ }^{30}$ The population of this parrot has decreased drastically since 1990. In 2007 it was estimated that the population of this parrot was only one bird per $\mathrm{km}$. One head per $\mathrm{km}$ covers an area of $11,500 \mathrm{~km}$. Vulnerable status is given to the Maluku parrot by the world conservation agency IUCN, The granting of a vulnerable status to the Maluku parrot is very dangerous for its existence in Indonesia. ${ }^{31}$

\section{c. The King Ambon Parrot Species}

This type of Ambonese parrot is often called just parrot. This animal in English is known as Moluccan King-parrot, Ambon King Parrot, or Amboina King Parrot. Whereas in Latin the Maluku endemic bird is called Alisterus amboinensis. The appearance of the Ambon King parrot is indeed unique. In addition to other parrots that have a bent beak, this $35-\mathrm{cm}$-long bird has 'vibrant' feathers and is striking with a combination of red, green and blue.

Ambon's Raja Nuri is one of the endemic rare birds in Maluku which is determined as the mascot of the Maluku province accompanying Larat Orchid as the flora of this province's identity, living in pairs or in small groups with a rather noisy chirp. Ambon's Raja Parrot consumes fruit, seeds, honey and shoots of plants. This bird lives in holes in trees. Marriage takes place around February to March. The global status of this bird species is greatly diminished. In addition to being reduced, this bird of shame has a rare status. Has a life of about thirty to forty years.

This type of bird is different in each region. First, amboinensis has the characteristics of a red lower head, a bronze or blue color located on the mantle and tail, the dominant tail color is black with a combination of purple and blue, while faded pink is found on the outer fur, have orange eye color, and black color is on the jaw. Meanwhile, the sulaenis do not have much difference. The difference lies in the color of the coat / fur that is on top has a green color and the tail does not have a pink color. Still the same species, there is a versicolor which has a difference in the coat of a bird that is blue and has the same size. But the size of this bird is smaller than the amboinensis type. ${ }^{32}$

\section{Forms of Activities in Protection Ecosystem in Maluku}

\section{a. Conduct Legal Protection Against Endemic Birds that Have Become Extinct in Maluku}

One of the efforts to provide legal protection for endemic ${ }^{33}$ endangered bird species is that the Government of the Republic of Indonesia promulgates Law Number 5 of 1990 concerning Conservation of Living Natural Resources and Ecosystems and Government Regulation Number 7 of 1999 concerning Preservation of Plant and Animal Species. In Article 19 paragraph (1), (2) \& (3) of Law Number 5 of 1990 concerning Conservation of Biological

\footnotetext{
${ }^{30} \mathrm{https} / / /$ www.mongabay.co.id/2015/03/09/si-burung-cantik-yang-terus-diburu/, accessed on October 2, 2020.

31 Ibid.

${ }^{32} \mathrm{https}$ ///www.parrots.org/encyclopedia/moluccan-king-parrot, accesed on October 2, 2020.

${ }^{33}$ Kevin C.W. Chen, Zhihong Chen, and K.C. John Wei, "LEGAL PROTECTION OF INVESTORS, CORPORATE GOVERNANCE, AND THE COST OF EQUITY CAPITAL,” Journal of Corporate Finance 15, no. 3 (2009): 273-289, 273, DOI: 10.1016/j.jcorpfin.2009.01.001.
} 
Natural Resources and their Ecosystems which regulates prohibitions on carrying out activities that may result in changes to the integrity of the nature reserve area. Legal substance is very important to guarantee the realization of minimum protection for the sustainability of ecosystems. Even though there are legal rules that form the basis of protection for various types of birds, but in the fact and practical area there are still many violations that occur.

Regulations regarding the prohibition to carry out activities that could result in changes to natural reserves are regulated in Article 19 which states:

First, every person is prohibited from carrying out activities which may result in changes to the integrity of the nature reserve area. Analysis based on the grammatical interpretation of the article shows that there is an element of minimum protection for the integrity ecosystem. Activities included in the elements of the article are concretely determined in the next article.

Second, the provisions referred to in paragraph (1) do not include the activity of fostering habitat for the benefit of animals within the animal clan sanctuary. If viewed from a grammatical interpretation that focuses on the aspect of a sentence clause, it can mean that this provision is appropriate to give special matters to the activities of developing ecosystems and their habitats. If no special provisions are given, it will cause new problems. The problem that will arise is that there is a possibility of error in punishing people who try to carry out activities with the intention of helping in efforts to improve the habitat of these animals. Based on other views, such as functional interpretation. The function of this article is useful as a justification for conservation activities and does not fulfill elements against the law.

Third, changes to the integrity of the nature reserve area as referred to in paragraph (1) include reducing, eliminating the function and size of the nature reserve area, as well as adding species of plants and other animals that are not native "While the regulations governing the prohibition of endemic endangered species are regulated in Article 21 paragraph (1), (2), (3) \& (4) which states, everyone is prohibited from:

1) Paragraph one contains activities that are specifically prohibited. There are eight activities that are rigidly prohibited by the regulation. These activities include capturing, injuring, killing, storing, possessing, maintaining, transporting and trading dead protected animals;

2) The second paragraph has a content that is quite specific and detailed. There are five activities that are in direct violation of this rule. The five activities are; Storing, owning, maintaining, transporting and displaying dead protected animals;

3) The content in the third paragraph has a wide scope. Specifically, this paragraph regulates activities related to activities with the international community. There are two activities that fall into the category of violations in the third paragraph; Removing protected animals from one place in Indonesia to other places inside or outside Indonesia;

4) More specifically in the last paragraph is preventive efforts to tackle the extinction of animals, because this paragraph regulates various activities that are prohibited from relating to the eggs / dwelling place of these animals. There are five activities; Taking, destroying, destroying, raising, storing or possessing eggs and / or nests of protected animals.

Based on these four provisions, it can be seen that the regulations regarding the protection of endangered animals are very detailed and specific. The activities are very clear and do not show any ambiguity in their definition. But this is not enough to provide full protection for endangered species in Indonesia. The action that must be improved is the enforcement of these arrangements. These arrangements must be obeyed by the parties and community.

\section{Other Efforts to Protect Endemic Kangka Species in Maluku, According to the Author}

Based on the author's analysis of the current regulations, the authors conclude that the current regulations are not sufficient to provide maximum protection for endangered species 
in Maluku and Indonesia. Progressive efforts must be made to protect rare species from the threat of extinction. Given that rare animals are an important asset for Indonesia in the field of environment and environmental law. Other efforts that must be made in the protection of endemic bird species that are almost extinct in Maluku. According to the author, there are four concrete solutions offered to the problems in this paper, these suggestions are

a. First, empowering customary law on indigenous peoples in Maluku, such as making customary sasi rules to protect endemic rare bird species that exist in Maluku;

The enforcement of customary law which has a strong binding power in the regions will be a solution to the problem of protecting rare animals, especially for bird species in Indonesia. Given that the existence of customary law is still recognized in the Indonesian legal system through the 1945 Constitution of the Republic of Indonesia.

b. Second, empowering religious instruments, to call on houses of worship against the prohibition of conducting illegal / illegal trade on endemic rare bird species in Maluku, prohibiting illegal logging in logging, hunting of endemic endangered bird species in Maluku;

The explanation of the solutions offered in this problem, second attempt is an action taken outside the legal context. Social aspects like this must be carried out consistently so that protection can run efficiently. The religious aspect is one of the means to raise awareness in society, because the characteristics of Indonesian society tend to be religious.

c. Third, make local regulations governing protection of endemic rare bird species in Maluku.

To realize the existence of regional regulations, it must be able to coordinate with the local government, because the regional government has the authority of it. Regional regulations that will be made and established must be harmonious with government regulations and laws regarding the protection of these rare species.

d. Fourth, make the Governor's Regulation, which regulates the protection of endemic rare bird species in Maluku, after regional regulations are formed and adjusted to existing regulations above, it becomes important to form a governor's regulation regarding the protection of endemic rare bird species in Maluku. The function of the governor's regulations in the protection of endangered animals is to be a concrete guide for law enforcers to act in accordance with the law.

\section{Conclusions}

One form of keeping peace to give birth to Harmony in the Land of the Kings in Maluku is implemented in the form of; togetherness, friendship, brotherhood, love between fellow children in Maluku, and can also be done in the form of a uterus, this will give birth to harmony among fellow people on one side and on the other hand will be more beautiful and have a high civilization value if people basudara in the Land of the Kings is to preserve the preservation of ecosystems in Maluku which will give birth to harmony between humans and nature (the environment). Between maintaining harmony between Basudara people in Maluku on the one hand and conserving ecosystems on the other, is a must for all components of the nation's children in Maluku, both of which are two sides of a coin which are very important in carrying out life on this earth so that the earth stay balanced, in harmony and will give birth to positive energy for the welfare of humanity. No less important than the two above, is the awareness of the people of Maluku to participate in creating harmony among fellow brothers and carry out protection and supervision of the survival of ecosystems, especially endemic rare bird species in Maluku. The Provincial Government of Maluku Province must encourage continuous awareness of both the general public and indigenous peoples in indigenous countries regarding the importance of maintaining peace and protecting and preserving the 
ecosystem, one of which is the endemic species of endangered rare bird species that exist in Maluku.

\section{A. Journal}

\section{REFERENCES}

Aarssen, L. W., Crimi, L. "BEYOND SIMPLE PLANNING: EXISTENTIAL DIMENSIONS OF CONVERSATIONS WITH PATIENTS AT RISK OF DYING FROM HEART FAILURE." Journal of Pain and Symptom Management 54, no. 5, 2017: 637-644, DOI: 10.1016/j.jpainsymman.2017.07.041.

Angga, La Ode. "PRINSIP KEHATI-HATIAN DI BIDANG PENGELOLAAN LINGKUNGAN HIDUP DALAM PERATURAN DAERAH RENCANA TATA RUANG WILAYAH PROVINSI MALUKU." Rechtidee 12, no. 1, 2017: 134-165, DOI: 10.21107/ri.v12i1.3130.

Bruckerhoff, Lindsey A., et al. "HARMONY ON THE PRAIRIE? GRASSLAND PLANT AND ANIMAL COMMUNITY RESPONSES TO VARIATION IN CLIMATE ACROSS LANDUSE GRADIENTS." Ecology 101, no. 5, 2020, DOI: 10.1002/ecy.2986.

Mendieta, Calvo., Iratxe., Petit, Olivier., Vivien, Franck-Dominique. "THE PATRIMONIAL VALUE OF WATER: HOW TO APPROACH WATER MANAGEMENT WHILE AVOIDING AN EXCLUSIVELY MARKET PERSPECTIVE." Policy and Society 30, no. 4, 2011: 301-310. DOI: 10.1016/j.polsoc.2011.10.006.

Casram. "MEMBANGUN SIKAP TOLERANSI BERAGAMA DALAM MASYARAKAT PLURAL." Wawasan: Jurnal Ilmiah Agama Dan Sosial Budaya 1, no. 2, 2016: 187198. DOI: $10.15575 /$ jw.v1i2.588.

Chen, Kevin C.W., Chen, Zhihong., Wei, K.C. John. "LEGAL PROTECTION OF INVESTORS, CORPORATE GOVERNANCE, AND THE COST OF EQUITY CAPITAL." Journal of Corporate Finance 15, no. 3, 2009: 273-289, DOI: 10.1016/j.jcorpfin.2009.01.001.

Gates, George A., Couropmitree, Nat N., Myers, Richard H. "GENETIC ASSOCIATIONS IN AGE-RELATED HEARING THRESHOLDS.” Archives of Otolaryngology-Head \& Neck Surgery 125, no. 6, 1999: 654-659, DOI: 10.1001/archotol.125.6.654.

Huijbers, Patricia M. C., et al. "ROLE OF THE ENVIRONMENT IN THE TRANSMISSION OF ANTIMICROBIAL RESISTANCE TO HUMANS: A REVIEW." Environmental Science \& Technology 49, no. 20, 2015: 11993-12004, DOI: 10.1021/acs.est.5b02566.

Mietzner, Marcus. "POLITICAL CONFLICT RESOLUTION AND DEMOCRATIC CONSOLIDATION IN INDONESIA: THE ROLE OF THE CONSTITUTIONAL COURT." Journal of East Asian Studies 10, no. 3, 2010: 397-424. DOI: 10.1017/S1598240800003672.

Nazmudin. "KERUKUNAN DAN TOLERANSI ANTAR UMAT BERAGAMA DALAM MEMBANGUN KEUTUHAN NEGARA KESATUAN REPUBLIK INDONESIA (NKRI)." Journal of Government and Civil Society 1, no. 1, 2018: 23-39, DOI: 10.31000/jgcs.v1i1.268.

Rosyadi, Irfan, et al. "PERILAKU MEMELIHARA BURUNG PARUH BENGKOK DI MALUKU UTARA." Acta VETERINARIA Indonesiana 3, no. 2, 2016: 51-57, DOI: 10.29244/avi.3.2.51-57.

Sagawa, Takahiro., Ueda, Masahito. "SECOND LAW OF THERMODYNAMICS WITH DISCRETE QUANTUM FEEDBACK CONTROL.” Physical Review Letters 100, no. 8, 2008: 40-80, DOI: 10.1103/PhysRevLett.100.080403.

Setiadi, Riswanda, et al. "A PEACE PEDAGOGY MODEL FOR THE DEVELOPMENT OF PEACE CULTURE IN AN EDUCATION SETTING." The Open Psychology Journal 
10, no. 1, 2017: 182-189, DOI: 10.2174/1874350101710010182.

Walker, Harry. "SOULFUL VOICES: BIRDS, LANGUAGE AND PROPHECY IN AMAZONIA." Tipiti Journal of The Society for the Anthropology of Lowland South America 8, no. 1, 2010: 1-21.

Winham, Gilbert R., Bovis, H. Eugene. "AGREEMENT AND BREAKDOWN IN NEGOTIATION: REPORT ON A STATE DEPARTMENT TRAINING SIMULATION." Journal of Peace Research 15, no. 4, 1978: 285-303, DOI: $10.1177 / 002234337801500401$.

\section{B. Books}

Angga, La Ode. Meraat Perdamaian dan Melestraikan Ekosistem Maluku. Ambon: Pattimura University Prees, 2017.

Otto, Soemarwoto. Analisis Mengenai Dampak Lingkungan. Yogyakarta: Gadja Mada University Press, 2005.

\section{Internet}

https://www.mongabay.co.id/2015/03/09/si-burung-cantik-yang-terus-diburu/, accessed on October 2, 2020.

https://travel.detik.com/travel-news/d-4600467/7-fakta-menarik-tentang-cendrawasih-siburung-surga, accessed on October,1 2020.

https://www.parrots.org/encyclopedia/moluccan-king-parrot, accesed on October 2, 2020. 